1979

\title{
Industrial Health and Safety
}

Harry J. Glasbeek

Osgoode Hall Law School of York University

Source Publication:

Legal Service Bulletin (now Alternative Law Journal). Volume 4, Issue 1 (1979), p. 12-18.

Follow this and additional works at: https://digitalcommons.osgoode.yorku.ca/scholarly_works (c) (1) $(9)$

This work is licensed under a Creative Commons Attribution-Noncommercial-No Derivative Works 4.0 License.

\section{Recommended Citation}

Glasbeek, Harry J. "Industrial Health and Safety." Legal Service Bulletin (now Alternative Law Journal) 4.1 (1979): 12-18.

This Article is brought to you for free and open access by the Faculty Scholarship at Osgoode Digital Commons. It has been accepted for inclusion in Articles \& Book Chapters by an authorized administrator of Osgoode Digital Commons. 


\section{A POLITICAL APPROACH}

\section{Industrial health and safety}

\section{H.J. GLASBEEK}

Nothing that we do to people in our society approximates the personal tragedy and victimization that is inflicted by bad working conditions upon people who are in a very poor position to defend themselves. workers'.

It is my view that although, in our various jurisdictions, we are developing more means to safeguard the worker against some of the worst excesses of injury that may occur at the workplace, the tools available to us are inherently deficient and will never guarantee even remotely satisfactory conditions for workers. I will briefly explain why this is so. The deficiencies arise out of implied assumptions which, if forced out in the open, would reveal the inhumanity of our socio-economic system. Such a revelation might lead to a fundamentalist approach to change. The lever I would like to use to reveal the genesis of the slaughter which we coyly term the "problem of safety and health in the workplace" is the application of the criminal law. I want to stigmatize employers for what they are: criminals.

As all employment situations inherently create some risk, to eliminate all risk of injury, logically, one ought to eliminate all enterprise. This is obviously an unacceptable means of approaching the problem. But it is put forward because it characterizes what is at issue: it is the fact of enterprise which creates the risk. The focus of any scheme which hopes to better conditions for workers has to be the nature of and control over the enterprise.

\section{TOOLS WHICH WE MIGHT USE TO IMPROVE WORK CONDITIONS}

(1) Many of the safety and health problems of employees find their origin in the very decision to set up the plant in a particular way. The location of a plant, the design and structure of buildings, the selection of equipment and machinery, the choice of 
particular materials for the processes of the plant, the choice of what products are to be manufactured. etc., all are decisions which vitally affect the working conditions of the employees. It could therefore be argued that no enterprise should ever be permitted to start up unless it has met tests designed by people who are partisanly interested in creating the best possible conditions for workers in the enterprise.

(2) Another means of control is the use of employers'/employees' health and safety committees, endowed with real powers. These joint committees ought to have the right to inspect the premises at all times, to make recommendations as to how to improve conditions, to inquire into complaints made by workers, and, if necessary, to close down the operation of the plant until matters have improved to the satisfaction of the committee.

(3) Unions should always bargain vigorously about health and safety conditions. The bargaining should include an insistence on a say in the introduction of new machinery or new materials to the manufacturing process, on the right to set up joint committees as described above, and always include a demand that costs of injuries should be borne by the employer to a larger extent than existing workmen's compensation schemes make him do.

(4) Statutory bodies could be set up to regulate health and safety conditions in workplaces. These would provide for standards of safety and health regulation with an inspectorate system which has the right to impose penalties and the right to stop operations until standards are met.

(5) From time-to-time it has been proposed that an injury tax should be levied on employers. The notion is that, every time a worker's injury or disease is attributable to work conditions, the employer is to pay an appropriate penalty into a fund. The point of this is that the employer would then be forced to focus on the financial need for better conditions. The tax would be collected by having the employer either declare the injuries to a safety and health agency just as he declares his income to the revenue authorities; or he would be subject to having workmen's compensation claims scrutinized and, from this scrutiny, an appropriate injury tax could be worked cut.

(6) Implicit in all of the above is a tool which must always be used, namely, education of people to the real hazards of working. This includes not only the people who work, employers and employees, but also unions as institutions, designers, engineers, architects, chemists, doctors etc.

\section{THE VARIOUS SCHEMES' DEFICIENCIES}

Most of the above means are in use to some extent in our various jurisdictions. They all fall far short of providing the protection which I see as a basic minimum.

Enterprise licensing: As it is impossible in our society to even begin to suggest that there should be no enterprise at all, we come down to the first of the tools suggested, namely that a licensing system should be introduced whereby no enterprise would be started unless an appropriate body agrees that as risk-free an environment as possible has been created. The notion that permits should be granted to enter into productive enterprise is, after all, not a

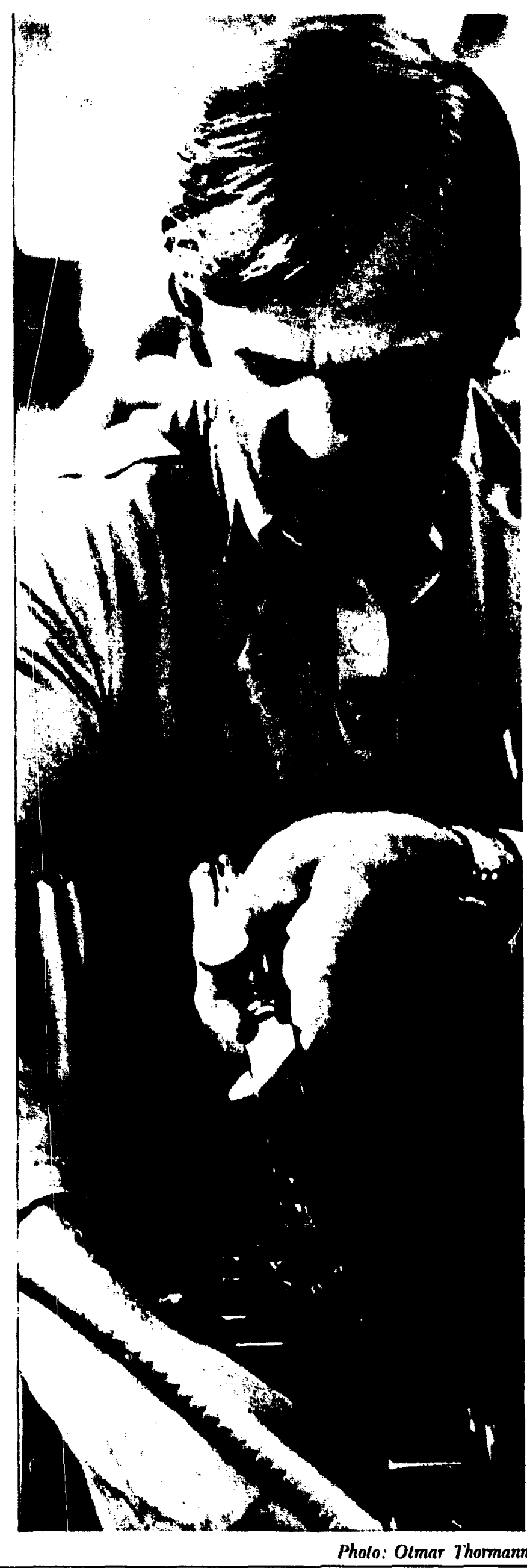


radical idea. We have long recognized that certain activities cannot be permitted to be self-regulatory. Thus, we do not let medical practitioners, lawyers $\boldsymbol{r}$ dentists practise without permits; we do not let bulld anywhere they like - we have zoning laws and permits' systems governing such activities; we do not permit anyone who wishes to set up a bank. The notion has been accepted whenever it is clear that large segments of the public would be adversely affected by uncontrolled behaviour. Somehow or other we have not yet felt the same urge to protect people who are at work. There the requirement of conformity to prescribed standards is imposed after the enterprise has been set up. The relationship between entrepreneur and the public is clearly viewed quite differently from that between the entrepreneur and his employees. The class bias of our system is thus emphasized. Because this bias is likely to persist, it is unlikely that we will go to a system of permits before enterprise can start up as a means of protecting workers. Profitability at the expense of workers' health is the implied assumption to which no-one in power would admit in public, but which is the factor which makes all of the tools presently used to protect workers deficient.

Trade union negotiation: To leave it to the bargaining ability of trade unions to protect workers also has clear demerits. It requires a great knowledge of occupational health problems by the trade unions. That knowledge does not yet exist. It will take a long time to acquire it. More importantly, trade unions have come to accept that the ownership of the modes of production is vested in employers and that, fundamentally, it is not the trade unions' role to wrest it away from them. This means that trade unions believe that their role is to improve the workers' share of the productive enterprise, rather than to change the relations of production. It is much easier to quantify improvement in terms of dollars than it is in terms of quality of working conditions. To do the latter, the trade unions, as institutions, must understand not only the nature of sccupational health hazards, but must also educate their rank and file to the same level of comprehension. Only then can the unions sensibly make arguments that it is more important to obtain safer working conditions than it is to get more money in their wage packets.

Note that I am assuming that trade unions will see safety and dollars as a trade-off. There is no logical necessity to make that assumption. But one of the corollaries of not questioning the relations of production has been that trade unions have come to accept that the easiest way to increase workers' income is to take the same share of an increasing cake, rather than make an attempt at cutting into the profit of the employer. The latter means, after all, would be a step in the direction of questioning the right to ownership. The ingrained belief that, in the long run, the share of both workers and employers is pre-destined by sacrosanct market principles, leads to the belief that an improvement in working conditions at the immediate expense of the employers will be an eventual expense to the worker.

Joint safety committees: Note further that when trade unions bargain about health and safety conditions, this bargaining does not come into play until the plant has been set up. That is, major managerial decisions which will affect the health conditions of workers have already been made and are very unlikely to be the subject of bargaining again. Thus, inasmuch as bargaining does take place, it cannot be very effective. Further, as unions are not interested in imposing too much cost on employers, their bargaining concentrates on obtaining the installation of relatively costless safeguards. They will seek to obtain some system under which they will be allowed to halt - as opposed to prevent - unsafe productive processes. In order to do this, they must have avallable to them information about the actual cond. itions of the plant and power to do something about unacceptable conditions. Many schemes of this kind have sprung up in North America. The most common are joint employer/employee safety committees with equal representation from both the employer and employees. These vary in sophistication. Some are merely allowed to inspect and report; others are actually to be given all the information available and may have power to make recommendations; others may even have the power to order a halting of production until conditions are remedied². So far they have not provided much improvement because, at best, they will come into play when conditions clearly fall below already-established standards. Where the evils are unknown or if known not remediable without great cost, the joint committees will not be in a position to be militant.

In Canada there are legislative schemes which impose joint committee systems ${ }^{3}$. Where they exist by dint of legislation it will be immediately apparent that they are subject to the vagaries of the political process. For instance, in Manitoba an extensive scheme of employer/employee joint committees, backed by a governmental inspectorate and standard-setting agency was set up but as soon as the government changed from a social democrat one to a truly conservative one, the inspectorate was diminished in number to such an extent, and the agency was given so little to do, that the scheme, although still in place, has been rendered totally impotent.

Regulatory agencles: The most noteworthy development of recent time has been the creation of statutory schemes of regulation ${ }^{4}$. Typically, they provide for the creation of an administrative agency which sets what it determines to be appropriate safety and occupational health standards and then, by a system of inspection, sets out to enforce the standards. There are models of varying sophistication. They all have built-in weaknesses. In particular, because diseases may have more than one cause, it is difficult to state with accuracy whether or not certain material environments will produce certain unacceptable health consequences. For instance, there are still arguments that there is no conclusive link between asbestosis and the use of asbestos!s Further, even where it is accepted that there is a fatal link, it is always open to dispute as to how much ex. posure to a particular material renders the environment unsafe. The difficulty in measurement arises because there is frequently a time lag between the exposure and the ensuing occupational disease. Inevitably, therefore, when the statutory body does its research in order to prescribe standards there is a great deal of respectable scientific opinion which varies tremendously in its recommendations. Part of the difficulty, no doubt, stems from the fact that 


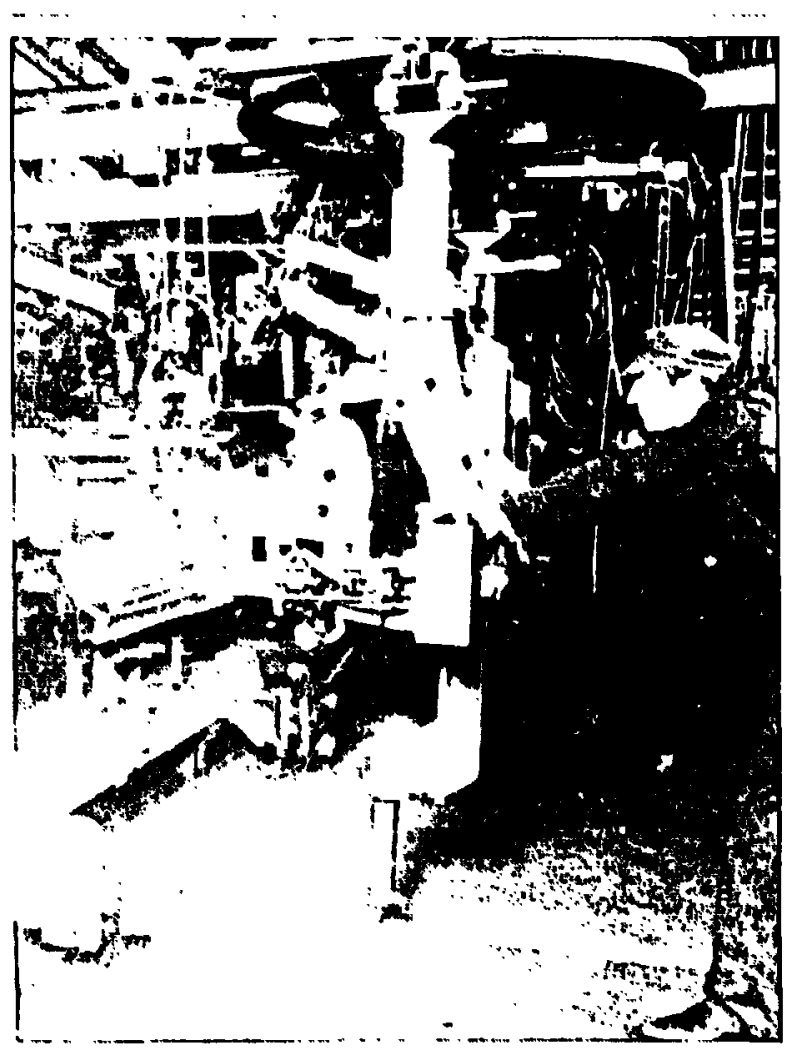

researchers are bought and sold in very much the same way as used cirs are". But, even if the agency has determined as a matter of scientific resolution that certain standards ought to be mel in the workplace. this does not mean that that agency will regulate those standards into effecl. The agency is created by the political process, and accepts its yround rules. It therefore accepts the basic proposition that one must not inhibit enterprise unnecessarily and, most importantly, that there must be a profit. It will. inevitably. seek a compromised optimum stan. dard for safety conditions. The compromise will be a balance between the need to make a goodly profit and the need to maintain a certain health standard. This kind of balancing trick defies imagination, but the courts have required the United States' Occupa. tIonal Salety and Health Act agency to do just that'. In a similar ven, because they depend for their appropriations on the political process. these agencies in eniorcing whatever regulations they finally put into effect must keep an eye on the most effective lobbyists in the country. Thus. a system of fines and the right to closure will be sanctions whose use may well depend upon which party is in powert. Typically. fines have been very low and inspectors have usually been told to help people sort out health problems rather than to entorce the statute.

An Injury Tax: Finally, the functional potential of the injury tax scheme may be doubled. Because the causal connection between a disease and the environment is not always easy to establish. it will be hard to know when to impose an appropriate tax. Secondly, the amount of the injury tax will be hard to gauge. If the size of the penalties presently imposed under regulations proscribing certain kinds of conduct are any indication. the likelihood of serious amounts being levied by way of injury tax is not very great Such a scheme might also have a backlash effect because people might be sacked if they are considered injury or disease-prone. There may be discrimination in hiring. Also as workmen's compen- sation legislation has done from time to time, injury tax schemes would provide an incentive to employers to hide the nature of hazard-creating enterprise. This could happen under any scheme devised, but there would be a greater incentive to do so under an injury tax scheme where the penalty is directly related to a particular injury or disease".

\section{A POLITICAL APPROACH}

At best, the miny proposials for mproviney lin:alth and siatety in the workforce are not likely to leatd to much improvement and mity. Indeded, be merely diversioniary Theretore, we neeed a menchillusm to con. vince: our leegisliaturs that it is peermissitsle: to atticck prolititbility of enterprise: where one: of the: costs of profitablity is the: physicial well beaticy of the: ceal produe ens and risk-tiakers in the: workpliece. the workers

What we need is atl allention-getter My proposil is that the: sertousmess and the: nidture of the? probsem may be: demonstrated by antalogical reaisonmy if the: physicial onsliugult whech lakess place: in the: workplace: occurred outside the? employer employee! environment or, if you will. ciapitalist worker context. there is no question but that society would use the: mosi formidatble tool it hiss to stop the vicious attiack it would use the crimmial process and treat the of fenders as heli ious social parlitlis Pruseculion of entreproneurs for the harm they do under the crimmal law proper. as opposed to siffety and health regulatory schemes, would characterize the conduct (which we presently excuse on the bisis of the inar. ficulated economic premise: that profit is God) for what it really is an unjustifiable proference for unregulated profit over the well-being of human beings who are the most important contribulors lowards the garnering of such profits

That is. if we can pin-point entreprencurial behaviour which inflicts grievous bodily harm or death as criminal conduct. then we will have employed a means to reveal the nature of the soclal entente we are supporting. It is my beliel that if this can be done il will be possible to discuss the necessary interference and regulation by government in a much more direct way. It may even be true that, within the context of a continuing capitalistic mode of production, we can get to talk about what is a reaisonable profit in light of a more acceptable mjury and disease rate. No-one. except real Neanderthals. will want to publicly adopt the posture that satisfying greed is more important thian the health and safety of human beings.

The use of the criminal process has another attrac. tion. Because law punishes behaviour which has been adjudged unacceplable by socicty no malter who the perpetrator of the ollensive behaviour is, it will be inlerestung to see how the administrators of the legal justice system respond when it is argued that entrepreneurs are offenders against the criminal process in much the same way as robbers of private property and assiulters of individual people for gain or pleasure. It will be something of an insight - if it is needed - if the officers of justice resist the application of the criminal process in the kind of situations that are posited in the following remarks. In and of itself this will demonstrate the class bias of law as well as the class bias of other forms of social organization. This is a political point which mily serve a purpose in itself. 


\section{AVAILABLE CRIMINAL OFFENCES}

I do not claim to be a criminal law expert, certainly not in respect of the Australian scene. I propose to identify the offences which are potentially useful to bring home criminal responsibility to employers who im. pose unbearable conditions on employees. It must be remembered that the purpose of the exercise is not to hang a few miscreants, but to focus attention on the fact that outrageously dangerous practices persist, thus pointing to the need for much more farreaching regulation than has taken place up to now and even, perhaps, new planning in the enterprise system of a kind which has never before taken place.

At the outset, note that in Canada criminal law has been codified'c, but that the Code is based solidly on the common law notions which are the basis for Australian criminal law. Inasmuch as the wording of the Code seems to make for differences, it is usually not so interpreted, the common law traditions prevailing in the collective judicial mind.

(1) Murder: One of the real problems with this offence, of course, is the proving of mens rea. Nonetheless, given the way that the offence has been defined, mens rea may be shown in some kinds of cases. Section 212(b) of the Canadian Criminal Code states that culpable homicide is murder -

(a) where the person who causes the death of a human being ...

(b) means to cause him bodily harm that he knows is Iikely to cause his death, and is reckless whether death ensues or not.

The difficulty here is obvious. Not only must an employer mean to do bodily harm (which with some ingenuity might be equated to knowingly doing bodily harm, although Canadian authorities do not suggest that this line of argument will be easily accepted), there must also be subjective knowledge of probable death as a consequence. This will be an almost insurmountable barrier, not the least because it may be very difficult to show that - objectively - death is a likely consequence of exposure of employees to particular toxic substances.

In Australia, the same difficulties stand in the way of successful murder charges. The law draws no distinction between an intention to kill and the foresight by the accused of certainty that death will ensue if certain conduct is undertaken. Subjective knowledge is nonetheless required and, again, this will be hard to prove where the relationship between substances used in enterprise and the diseases which cause death are still matters of some scientific controversy. Nonetheless, murder is not to be neglected as a potential head of criminal responsibility. The foresight which is necessary before it may be equated with intention is, in fact, foresight of high probability of death. Take a plant where asbestos is processed. Would it not be plausible to argue that everyone knows that it has potentially lethal qualities? If so, the basic political issues will have to be confronted by a court: if it is held not to be murder to have someone die as a result of exposure to asbestos, the court must acknowledge that it has made a judgment that the process involving the known dangerous use of asbestos is, by reasoning not applicable to the dangerous use of a motor car or gun, not the kind of activity which attracts criminal responsibility. Professor Howard, in his criminal law text writes:
Apart from the usual detences to a charge of murder, there are some situations in which foresight of cer. tainty that one's actions will cause the death of another is not equivalent to intention to kill. For example, $D$ may be in charge of a dangerous constructional operation such as tunnelling through a rock. It may be a statistical certainty that over a period of one month at least one man in the number under his command will be killed. D will nevertheless not be guilty of murder if he knows the statistics and orders the work to proceed. It is difficult to draw a satistactory distinction between cases where foresight of certainty is equivalent to intention in murder and cases where it is not. The difterence does not lie in the introduction of statistics, for these, when used predictlvely, merely express a degree of probability in a conveniently exact form. Neither does the difference lle in the lawfulness of D's activity for, apart from the homicide, a man lawfully blasting holes in rock would be guilty of murder if he knew that by setting off the charge he would certainly kill a trespessing onlooker".

Although Professor Howard clearly thinks it too ob. vious to state why it is that the tunnelling example does not present a situation of murder, he leaves no doubt as to what he believes. For our purposes it has to be stated: in such a "useful" operation as tunnelling through a rock, the certainty of death does not make the risk which is deliberately run criminally un. justifiable. That is, criminal law has built in it the notion that some deliberate killing is permissible. This raises our question: when is it justiflable to sacrifice life to enterprise? To force that issue into open court may have tremendous catalytic value.

In Canada, the possibility of raising that issue, which I perceive to be the issue to bring to the public fore, is aided by section 212(c) of the Criminal Code. It provides that culpable homicide is murder (c) where a person, for an unlawful object, does anything that he knows or ought to know is likely to cause death, and thereby causes death to a human being, notwithstanding that he desired to effect his object without causing death or bodily harm to any numan being.

The jurisprudence on this section is that there must be an unlawful act leading to the death and that this unlawful act is to have a separate unlawful object over and above the causing of bodily harm or death. Thus, on its face it would not be sufficient to say that the act causing death, say, lack of provision for sufficient ventilation, was unlawful because it was in breach of a safety statute. Arguably, it could be said that that breach of a statute had as its object a desire to breach the common law duty that every master owes to his servant to provide safe premises and that, therefore, an unlawful act with an unlawful ob. ject had been committed. This argument has logical plausibility but it may be difficult to put it successfully simply because it has never been used before.

Recent case law, however, has held that an unlawful act, such as a breach of a statute or of the common law duty owed by a master to his servant, may have the unlawful objective of being a conspiracy if several people agreed to engage in the unlawful act. It has further been held that if the achievement or the attempted achievement of this unlawful objective - conspiracy - led to death, murder would have been committed. This is most promising for my purposes, especially in view of the political aim which I wish to further. If a case can be brought 
on this basis it will inevitably be essential for the prosecution to adduce evidence to the effect that the reason for being in breach of the common law duty to provide safe premises and working conditions is to make more money, regardless of the physical wellbeing of the worker. Attention would thus be focussed on the primary issue.

(2) Criminal Negligence: The following provisions of the Canadian Criminal Code seem to be extremely useful:

202.(1) Everyone is criminally negligent who -

(a) in doing anything, or

(b) in omitting to do anything that it is his duty to do, shows wanton reckless disregard for the lives or satety of other persons.

(2) For the purposes of this section "duty" means a duty imposed by law.

203. Everyone who by criminal negligence causes death to another person is guilty of an indic. lable offence and is liable to imprisonment for life.

204. Everyone who by criminal negligence causes bodlly harm to another person is guilty of an indictable offence and is llable to imprisonment for ten years.

Although it is a fundamental principle of Canadian criminal law that before one can be convicted of a criminal offence, including criminal negligence, the prosecution must establish that the accused had the requisite mens rea, it is my reading of the case law on criminal negligence that a conviction may be ob. tainable if it can be shown that the conduct of the accused involved a risk whose likelihood of materializing, and the gravity of harm which would ensue should it materialize, cannot be justified as being a reasonable risk to take. Once again, therefore, the use of this offence would focus attention on the justification for the running of risks in enterprise. Not only is this politically satisfactory; there is, in fact, hope for success. In a recent safety accident situa. tion in Quebec a coroner actually recommended that criminal negligence charges ought to be laid against the employers. The facts were that the employer knew that employees and inspectors were perturbed by the lack of ventilation in some underground work. When the workers were in fact overcome by poisonous gases, the coroner was convinced that the risk taken by the employer in ignoring safety precautions which they had been advised to take was simply not justifiable.

It is my understanding that in Australia much of the same argument would apply. I refer here to Howard's criminal law text again'2. To illustrate his point Howard uses the case of Lowe ${ }^{13}$. In that case the accused was in charge of bringing people in a mine up to the surface by elevator. He delegated this task to a boy who, he knew, did not understand the opera. tion of the machinery. The ensuing deaths led to a finding of manslaughter against the foreman. The analysis used by the court was clear: where there is a person who has a statutory duty to look after the well-being of others, that person will be held criminalIy responsible for foreseeable harm arising out of a dereliction of duty. Manslaughter will be found where the accused takes an unjustiflable risk in view of the likelihood of injury and the gravity of that injury. Subjective intent, as it is commonly defined, will not need to be shown.
(3) Offences avallable under the Canadian Criminal Code for which there may be no Australlan Equivalent:

201. Every master who

(a) unlawfully does, or calises to be done, bodlly harm to h/s apprentlce or servant so that hls llfe is endanger. ed or his health Is, or is Ilkely to be permanently injured, ...

is guilty of an indictable offence and is $11 a b l e$ to $\mathrm{im}$. prisonment for two years.

This section, on its face, is very useful. But it is an assumption in the Criminal Code of Canada that mens rea has to be established in respect of every offence, whether or not it is expressly included. But, of course, there are many shades of mens rea and it may be plausible to raise an argument here. As far as I know, no case has ever been brought under this section.

380.(1) Everyone who wilfully breaks a contract, knowing or having reasonable cause to belleve that the probable consequences of doing so, whether alone or in combination with others, will be -

(a) to endanger human Ilte,

(b) to cause serlous bodlly injury, ... is guilty of .

(t) an indictable offence and is llable to imprisonment for five years, or

(g) an olfence punishable on summary conviction.

Again, on its face, this promises a great deal. The difficulty with it is that 'wilful' has to be interpreted in the mens rea sense. Again there has been no interpretation that I know of, so there may be possibilities here. This requires exploration.

(4) Conspiracy: Under the Canadian CrIminal Code the appropriate sections are sections $423(1)(d)$, $423(2)$. It is a conspiracy to wish to combine to com. mit any of the offences already listed above or to conspire with anyone to effect an unlawful purpose or to effect a lawful purpose by unlawful means. Clearly it will be a conspiracy to agree to commit an act in breach of statute or to violate the contractual provision requiring a safe system of work; and it may even be arguable that to attempt to save money (which is a lawful purpose) by breaching such statutory or common law duties will also be a conspiracy. This, therefore, is a most promising set of provisions. It is rather piquant to think that these sections might be usable, because conspiracy is usually used against accused people as a means whereby the Crown can get convictions when actual proof of offence by Individuals is hard to come by. I believe the law is much the same in Australia.

\section{SOME BASIC DIFFICULTIES WITH USING THE CRIMINAL PROCESS}

Time limits: In respect of potential charges for murder it must be noted that death must occur within one year and a day of the actus reus of the accused having occurred. Exposure to toxic substances sometimes leads so debilitation and eventual death only many years after the original contact occurred. There will be difficult questions as to the time from which one starts counting the period of a year and a day. Do note that, in this context, in criminal negligence there is no need to establish that death occurred in Canada and, therefore, that problem may be eliminated. 
Causation: A problem that will raise its head, as it does in all criminal and torts cases, is causation. In theory it is no different here than it is in the civil law. Thus, although the state of empirical knowledge may be such that we cannot clearly establish a connection between the use of certain toxic substances and particular diseases, this does not necessarily mean that criminal charges cannot be successfully brought. It seems to me that the arguments that are used in torts cases in respect of causation will be applicable to criminal ones. I simply note that there are many torts cases in which the use of toxic substances leading to injury has been held to provide a sufficient causal connection 14 .

Criminal Responsibility of Corporations: Many of the employers will be corporations. Is there a difficulty about hringing criminal offences against corporations? As a matter of social policy there are concep. tual difficulties. In particular, where subjective intent is required to establish a criminal offence it is always arguable that a corporation can have no such intention. Whatever may be the merits of this argument as a matter of strict theory, it seems to be now unquestioned that corporations can be made liable for conduct which would lead to conviction in individuals. In Canada, the Criminal Code provides specifically's that where corporations are held responsible for conduct which would lead to corporal punishment in respect of an individual the corporation may be convicted and be saddled with a fine. In his text ${ }^{16}$, Howard writes that:

It may be thought that the natural limitations on the power to punish a corporation imply that there are some crimes, notably offences against the person, that a corporation cannot commit. There seems to be no warrant for this. No theoretical reason suggests itself why, if it can be within the scope of a managing director's employment to commit traud in what he supposes are the company's financial interests, he should not equally well be within the scope of the employment to commit murder, or any other offence against a person, with the same object. It is highly im. probable that any good would come out of pro. secuting the company, as opposed to the managing director, and it is clear that the usual punishment for murder could not be imposed. These considerations, however, have no logical bearing on the company's criminal responsibility.

Discretion to Prosecute: The remaining major difficulty that I envisage is the fact that the forces of prosecution would not be very keen to proceed to trial with fact situations in which employers are being sought to be made criminally responsible for the conduct of their enterprise. In Canada, it is possible for individuals to lay private informations. In my view academics are ideally placed to institute such proceedings. They can wait for the right fact situation to be brought to them by willing unions and then, without any risk to the particular unions or individuals involved, lay the information. It is still for Crown prosecutors to decide whether or not they will proceed with the action. The Crown prosecutors may very well refuse" ${ }^{17}$. Should the official Crown prosecutor refuse to take an action where the fact situation and the theory of the law suggest that a crime has been committed, this in itself will be politically useful because it will have been made clear that the law is being applied in a lopsided manner to protect certain kinds of entrepreneurs in situations where other people would not get such protection. Indeed, it is my purpose to show that, if the law were neutrally applied, it is theoretically capable of being applied to the enterprise-occupational health area.

\section{FOOTNOTES}

1. From Working Papers for a New Society (May/June 1978): Boder and Wegman, "Increasing OSHA's Clout: Sixty Million New Inspectors".

Every year roughly 14,000 American workers are killed in on. the-job accidents; more than two million are injured. Fatalities from lob-related illnesses are estimated laccurate data is scarce) to run at 200,000 a year.

2. The most far-reaching agreement of this kind I know of is that between UAW and Geireral Motors in Ontario. There are many variants, but remember that in this jurisdiction only one-third of the people who work are unionizer, and a great percentage of those are in public-sector $t$ mployment where risks are relatively low.

3. E.g., The Ontario Occupational Heallh and Satety Act. 1977; An Act lor the Promotion and Prolection of the Health and Salety of Persons Engaged in Occupations S.S. 1972, c.86; The Workplace Safely and Health Act, S.M. 1976. c.3: Canada Labour Code, R.S.C. 1970, c.11.1 las am. 1976-77, c.27).

4. The Canadian statutes cited above embody such schemes, but the most-tested and sophisticated one is the Occupa. tlonal Salely and Health Act, 29 U.S.C., para. 651.

5. See T. Alexander, "OSHA's Ill-Concelved Crusade Against Cancer" in Fortune, 3 July 1978, p.86.

6. This needs no documentation!

7. See Industrial Union Department, AFL.ClO v Hodgson, 499 F. 2 d 477.78 (D.C.C.A.); Floride Peach Growers' Association v United States Department of Labor, 489 F. 2d 120 , 130 (5th circ. 1974).

8. A most spectacular instance is recorded by Randall "Worker Safety and Politics" - in the Washington Star. 15 July 1974: a letter by a Nixon aide to the Occupational Health and Safety Agency containing the following was reported:

No highly.controversial standards (that is cotton dust etc.)... be proposed by OSHA or NIOSHI [because of] the great polential of OSHA as a sales point lor lund-raising and general supporl by employers.

And in the hearings before the Senale Select Committee on Watergate, the then Undersecretery for Lebor said that it would have been pertectly legitimate to say that OSHA would more nearly balance the relative interests of workers and employers under a Republican than under a Democratic Administration.

9. This argument is more fully made in Working Papers etc., n. 1, above.

10. Criminal Code, R.S.C. 1970, c.C.34,

11. Aistralian Criminal Law (2nd ed., 1970), pp.46.47.

12. pp. 107 et seq; and also in the section "The Concept of Awareness", pp.348 et seq.

13. (1850) 3 C.\& K. 123

14. Some well-known torts cases in which the causal connection between substance and injury was found to exist are Bonnington Castings Lid. v Wardlaw [1956] A.C. 613, Nicholson v Allas Steel Foundry and Engineering Co. Ltd. [1957] 1 W.L.R. 613, Smith v Central Asbestos Company; Central Asbestos Co. Lid. v Dodd [1972] 2 All E.R. 1135; McGhee $\vee$ Nallonal Coal Board [1973] 1 W.L.R. 1. Note that finding that the causal connection exists may be easier for courts in civil cases than in criminal ones, but that logically this does not go to whether or not in fact there is a causal connection. The question of burden of proof on this point is no different. The danger is that the mens rea may be said not to exist when there is some doubt thrown on the causel connection.

15. Section 647 .

16. Op.cit., p.384

17. In Ontario, there is provision for prosecutions to be brought by Special Crown prosecutors. The notion is that these people will take on cases which otherwise might not be pursued. 